\title{
Road Accidental Analysis and Identify the Black Spot
}

\author{
${ }^{1}$ Jaffar Hussian Meer \\ Student \\ CT University
}

\author{
${ }^{2}$ Sukhdeep Singh \\ Assistant professor \\ CT University
}

\author{
${ }^{3}$ Komalpreet Singh \\ Assistant professor \\ CT University
}

\begin{abstract}
The increase in motor vehicles accompanied with expansion of roads has brought with it the challenge of addressing the adverse influence of road traffic accidents. Road incidents are a nationwide cataclysm with ever increasing trend which incurs a human health and development challenge and highly affect the human capital development of every nation. A mortality rate database (WHO, 2002) assures that India has highest number of accidents. Accident Black Spots are those locations on the road which have higher severity of accident either in terms of numbers or in terms of injuries. In this paper, efforts have been made to identify the location of accident black spots on national highway from singhpora pattan to panthachowk srinagar.The present era accidents are contributing major deaths worldwide due to increase in vehicular traffic.It has been estimated that every year 1.38 lakh lose their limbs and 6 lakh people get injured in road accidents in india.our country incurs a loss of 58000 crore each year due to road accidents.
\end{abstract}

The most used roads to travel from jalandhar in punjab to uri in kashmir is NH-1A.The old name for $\mathrm{NH}-44$ is NH-1A which was replaced after renumbering of all national highways in year 2010 .
In this report,the analysis includes study of some major accident spots or busy intersections in the NH-1A in between Pantha chowkh Srinagar to Singhpora Pattan.The study includes visiting sites,collecting required data for analysis and derives the results and remedies from what we had got.

This report will be containing the material surveyed,pictures of road at different locations, road details,figures,material for understanding of the unknown and finally the conclusion.

\section{INTRODUCTION}

It is well said that each turn of wheel is that the revolution ahead in terms of development, but depending on other side we may say that road traffic accidents pose threat to mobility. Injuries from Road traffic accidents are a global public health concern. Amongst all traffic accident, road traffic accident bears largest number of human life and tends to be most serious problem world over. Road accidents are largely predictable and preventable; provided rational analysis and countermeasures.

Details of accidents on NH1A in Srinagar district in year 2018 and 2019 :

\begin{tabular}{|c|c|c|c|c|c|c|c|}
\hline S No. & $\begin{array}{l}\text { Time- } \\
\text { (hrs) }\end{array}$ & $\begin{array}{l}\text { FIR- } \\
\text { no. }\end{array}$ & Location- & $\begin{array}{c}\text { Fatal- } \\
\text { Y/N }\end{array}$ & Road Condition & $\begin{array}{l}\text { Type Of } \\
\text { Collision }\end{array}$ & Reason \\
\hline 01 & 1445 & 54 & Pantha-chock & $\mathrm{Y}$ & Smooth & Hit and run & Over speed \& carelessness \\
\hline 02 & 1030 & 85 & $\begin{array}{l}\text { Peaks auto- } \\
\text { mobiles lasjan }\end{array}$ & $\mathrm{N}$ & $\begin{array}{c}\text { Under } \\
\text { construction }\end{array}$ & Head on & Over speed \& carelessness \\
\hline 3 & 1100 & 87 & $\begin{array}{l}\text { Peaks auto- } \\
\text { mobiles lasjan }\end{array}$ & $\mathrm{N}$ & $\begin{array}{c}\text { Under } \\
\text { construction }\end{array}$ & Rear side & Sharp turn with over speed \\
\hline 04 & 0130 & 47 & Nala kadal lasjan & $\mathrm{Y}$ & $\begin{array}{c}\text { Under } \\
\text { Construction }\end{array}$ & Head on & Over speed \& carelessness \\
\hline 05 & 2048 & 08 & Pantha chock & $\mathrm{Y}$ & Smooth & Head on & Over speed \& carelessness \\
\hline 06 & 2032 & 07 & Zewan crossing & $\mathrm{N}$ & Smooth & $\begin{array}{l}\text { collision with } \\
\text { footpath }\end{array}$ & Over speed \& carelessness \\
\hline 07 & 2230 & 44 & Zewan crossimg & $\mathrm{Y}$ & Smooth & $\begin{array}{c}\text { Head tail } \\
\text { between motor } \\
\text { vehicles }\end{array}$ & Over speed \& carelessness \\
\hline 08 & 0706 & 59 & Zewan crossimg & $\mathrm{N}$ & Smooth & $\begin{array}{c}\text { Head tail } \\
\text { between motor } \\
\text { vehicles }\end{array}$ & Over speed \& carelessness \\
\hline 09 & 1400 & 28 & Athwajan & $\mathrm{N}$ & $\begin{array}{l}\text { Having } \\
\text { Pot holes }\end{array}$ & Head on & Vehicular overloading \\
\hline 10 & 2030 & 32 & Athwajan & $\mathrm{N}$ & Smooth & $\begin{array}{c}\text { Collision with } \\
\text { divider }\end{array}$ & Over speed \& carelessness \\
\hline
\end{tabular}


ISSN No:-2456-2165

\begin{tabular}{|c|c|c|c|c|c|c|c|}
\hline 11 & 0810 & 52 & Athwajan & $\mathrm{N}$ & Smooth & & $\begin{array}{c}\text { Over } \\
\text { - turning }\end{array}$ \\
\hline 12 & 1815 & 24 & $\begin{array}{c}\text { Nowgam chock } \\
\text { (sbi) }\end{array}$ & $\mathrm{N}$ & Smooth & Side on & Over speed \& carelessness \\
\hline 13 & 1500 & 70 & Nowgam chock & $\mathrm{N}$ & Smooth & Head tail & Overtaking \\
\hline 14 & 1515 & 88 & $\begin{array}{c}\text { J\&k bank } \\
\text { nowgam }\end{array}$ & $\mathrm{N}$ & Smooth & Hit and run & Over speed \& carelessness \\
\hline 15 & 1815 & 103 & Nowgam chock & $\mathrm{Y}$ & Smooth & Head tail & Over speed \& carelessness \\
\hline 16 & 0720 & 130 & Nowgam chock & $\mathrm{N}$ & Smooth & Head tail & Over speed \& carelessness \\
\hline 17 & 0730 & 138 & Nowgam chock & $\mathrm{N}$ & Smooth & Head on & Over speed \& carelessness \\
\hline 18 & 2030 & 139 & Nowgam chock & $\mathrm{Y}$ & Smooth & Head tail & Over speed \& carelessness \\
\hline 19 & 1130 & 143 & $\begin{array}{c}\text { Peaks auto- } \\
\text { mobiles }\end{array}$ & $\mathrm{Y}$ & Smooth & & $\begin{array}{c}\text { Over } \\
\text {-turning } \\
\end{array}$ \\
\hline 20 & 1830 & 150 & $\begin{array}{c}\text { Masterpro } \\
\text { college } \\
\text { Bypass }\end{array}$ & $\mathrm{Y}$ & Smooth & Head tail & Over speed \& carelessness \\
\hline
\end{tabular}

Table 1

The process of eliminating or improving accidental black spots in a road network is composed of various activities as given below:-

- Identification of black spots: is that the procedure to locate those spots within the road network that are particularly dangerous, that is, the identified black spots

- Finding countermeasures: Implies a methodical analysis to style suitable countermeasures for every plant disease, supported actual problems and deficiencies black spots.

- Diagnosis: Is that the process to review what are the issues, the accident contributing factors and therefore the deficiencies for every of the identified black spots.

- Estimating effects: Is that the process to estimate the security effects (and if necessary also other effects) and costs of suitable countermeasures.

- Prioritizing: Implies finding the simplest action plan (or investment program), consistent with some defined criteria, and supported estimated effects and costs also as budget restrictions.

- Implementation: Is that the actual realization of the prioritized measures included within the action plan (or investment program).

- Follow-up and evaluation: Is that the last and really important step, which aim is to assess the particular results (effects and costs).

Road selected for our study map is a small length from the NH-1A which itself runs from Jalandhar in Punjab to Uri in J\&K. NH-1A runs for a complete length of 663 $\mathrm{kms}$ and is maintained by NHAI.

Accident analysis or accident investigation is administered so as to determining the cause of an accident or series of accidents So on prevent further incidents of an identical kind. It' $s$ going to be performed by a variety of experts, including forensic scientists, forensic engineers or health and safety advisers. Black spot analysis is completed by engineers to see the necessity of redesigning an intersection or assigning signs or signals along the road, to save lots of lives and property.

\section{LITERATURE REVIEW}

In February this year, while taking serious note of frequent road accidents, including the national highways and remote areas, Lt Governor of Jammu and Kashmir had approved a road safety action plan.

The salient features of the policy include: Centre of Excellence to be established across the state to create capacity in road safety research, raising awareness among key decision makers, stakeholders and NGOs to facilitate them in planning and promoting road safety, implementation of road safety initiatives. The action plan also envisioned creating trauma healthcare facilities on the highways, funding for road safety initiatives, establishment of safe transport infrastructure and stringent enforcement of traffic laws.

Dr. S. S. Jain ET. al. (2011) found that trucks are parked on highway which reduces the effective width of carriageway and creating traffic hazards to high speed moving traffics. Unauthorized median openings were found which should be immediately closed. Missing roads and median markings is to be done and necessarily speed should match with speed signs. Access and service lanes are also deficient which requires immediate improvement. The most Vulnerable Road User (VRU) i.e. pedestrians and cyclists facilities near habitation are lacking and needs to be facilitated on priority.

Dr. Wen Long YUE et al. (2001) provides all the information which is related to various functions and tools of accident studies in GIS. GIS is suitable for analysis of spatial data, graphic display and visual interface etc. Such features have important applications for identification of traffic safety problems. The paper presents the process which includes the formation of black spot and how these black spots are then analyzed in GIS using information query tool for peak hour accidents,accidents at night times, accidents involving pedestrian, etc. 
In literature there is no universally accepted definition of a black spot. According to The Bureau of Transport and Regional Economics of Australia (2001) the certain locations are in general assigned as black spots after the assessment of the level of risk and the likelihood of a crash occurring at each location. In certain sites, their will be high level of risk than their neighbouring areas. Crashes will tend to occur more at these relatively high-risk locations. Those locations which have an usually more number of accidents are described as crash concentrated, high hazardous, hot spots or black spot sites. The Sites with potentially hazardous features are often sometimes called as grey spots.

\section{$>$ Objective of the Study:}

- To identify and classify Accident Black Spots on NH1A from Pantha chowk Srinagar to Singhpora Pattan road using the developed methodology

- To seek out various accident causing factors and to spot the foremost vulnerable segments.

- To match the foremost vulnerable segments with Accident Black Spots and supply suitable counter measures.

\section{Study Area:}

This study was carried out on national highway NH1A, starting from singhpora pattan to pantha chowk Srinagar. The study stretch is $34 \mathrm{~km}$ long. It is a measure artery of commerce and public transport, and is witnessing major construction boom along its root to Narbal Srinagar. It has emerged as a hub for entertainment and corporations. This stretch consists of many intersections, underpasses, over bridges with very poor visibility and ribbon development. The stretch is busy with large number of traffic and for many years the traffic density has risen up.

\section{METHODOLOGY FOR IDENTIFICATION OF ACCIDENTAL BLACK SPOTS}

\section{Data Collection:}

The basic plan was to collect data from the police stations and they were very cooperative with us .we faced a few problems at first and nothing happened with ease . we collect the data from four police stations respectively

- Police station pantha chowk srinagar

- Police station nowgam Srinagar

- Police station parimpora Srinagar

- Police station mirgund baramulla
We then observed the main intersections on the road were accidents can occur or do occur. We searched the literature on black spots in the state . we clicked pictures at all intersections coming under the area of survey. understanding the concepts came from our my friends and some books, and from internet sources . current conditions of road was observed by travelling in person along the road .Results were derived from the keen observations of the sites and the knowledge we have got during our studies.

The primary data includes the road inventory servey administered on the highway to study various factors that may directly or indirectly add to the reasons behind the accidents. Based on literature review and experience following are the important factors considered:

- Number of lanes in each direction.

- Availability of traffic signs and road markings.

- Drainage conditions.

- Availability of pedestrian crossings.

- Effect of merging and converging traffic.

\section{$>$ Identification of Black Spots}

To identify accidental black spot the method used is KGM is named as Rate-Quality-Control method. It is a statistical procedure for identifying black spots. A statistician at the Swedish national road and transport research institute (Mats wiklund) has scrutinized the tactic. The theory part of this paper is based partly on his comments.

The Rate-Quality-Control Method consists of calculating three different parameters for every road section. The three parameters are:

- Accident rate.

- Accident frequency.

- Severity index.

Each of these values is compared with a critical value. Thus the accident rate is compared with one critical value, the accident frequency with another critical value and therefore the severity value with a third critical value. If a particular road section shows higher values than the critical ones of these three parameters, the section is taken into account as black spot.

Accident rate: $\mathrm{M} / \mathrm{L}$

Where $\mathrm{M}=$ Total number of accidents in a stretch, $\mathrm{L}=$ Road length

\begin{tabular}{|c|c|c|c|}
\hline Name of stretch & Length & No. of accidents & Accident rate \\
\hline Singhpora to Mirgund & $16 \mathrm{~km}$ & 438 & 27.4 \\
\hline Mirgund to pantha chowk & $18 \mathrm{~km}$ & 384 & 21.4 \\
\hline
\end{tabular}

Table 2:- Accident rate 


\begin{tabular}{|c|c|c|c|}
\hline Distance of origin & Frequency & No. of accidents & Total frequency \\
\hline $0-8$ & 30.5 & 238 & 30.5 \\
\hline $8-16$ & 31.6 & 217 & 62.1 \\
\hline $16-24$ & 3.4 & 261 & 65.5 \\
\hline $24-34$ & 34.3 & 238 & 100 \\
\hline Total & 100 & 954 & \\
\hline
\end{tabular}

Table 3:- accident frequency

Severity Index:

It denotes the vulnerability of a particular spot of accidents.

The accidental cause in existing data is given below :

- Overturning

- Head on collision

- Rear end collision

- Collision brush
- Right turn collision

- Skidding

$\mathrm{SI}=\mathrm{B} / \sum \mathrm{W} \times 100$

Where $\sum \mathrm{W}=\mathrm{w} 1+\mathrm{w} 2+\mathrm{w} 3 \ldots \ldots$

SI benchmark : the SI value above SI benchmark is considered as black spot

\begin{tabular}{|c|c|c|c|c|c|c|c|c|c|}
\hline S. No. & Chainage & 1 & 2 & 3 & 4 & 5 & 6 & $\mathrm{~B}$ & SI \\
\hline 1 & 2.0 & $\mathrm{~N}$ & $\mathrm{~N}$ & $\mathrm{~N}$ & $\mathrm{~N}$ & $\mathrm{~N}$ & $\mathrm{~N}$ & 0 & 0 \\
\hline 2 & 7.0 & $\mathrm{~N}$ & $\mathrm{~N}$ & $\mathrm{Y}$ & $\mathrm{N}$ & $\mathrm{N}$ & $\mathrm{N}$ & 6 & 28.57 \\
\hline 3 & 9.0 & $\mathrm{~N}$ & $\mathrm{~N}$ & $\mathrm{Y}$ & $\mathrm{N}$ & $\mathrm{N}$ & $\mathrm{N}$ & 6 & 28.57 \\
\hline 4 & 12.0 & $\mathrm{~N}$ & $\mathrm{~N}$ & $\mathrm{Y}$ & $\mathrm{N}$ & $\mathrm{N}$ & $\mathrm{N}$ & 6 & 28.57 \\
\hline 5 & 15.0 & $\mathrm{~N}$ & $\mathrm{~N}$ & $\mathrm{Y}$ & $\mathrm{N}$ & $\mathrm{N}$ & $\mathrm{N}$ & 6 & 28.57 \\
\hline 6 & 17.0 & $\mathrm{~N}$ & $\mathrm{~N}$ & $\mathrm{Y}$ & $\mathrm{N}$ & $\mathrm{N}$ & $\mathrm{N}$ & 6 & 28.57 \\
\hline 7 & 19.0 & $\mathrm{~N}$ & $\mathrm{~N}$ & $\mathrm{~N}$ & $\mathrm{~N}$ & $\mathrm{~N}$ & $\mathrm{~N}$ & 0 & 0 \\
\hline 8 & 23.0 & $\mathrm{~N}$ & $\mathrm{~N}$ & $\mathrm{Y}$ & $\mathrm{N}$ & $\mathrm{N}$ & $\mathrm{Y}$ & 11 & 52.38 \\
\hline 9 & 27.0 & $\mathrm{~N}$ & $\mathrm{~N}$ & $\mathrm{Y}$ & $\mathrm{N}$ & $\mathrm{N}$ & $\mathrm{N}$ & 6 & 28.57 \\
\hline 10 & 31.0 & $\mathrm{~N}$ & $\mathrm{~N}$ & $\mathrm{Y}$ & $\mathrm{N}$ & $\mathrm{N}$ & $\mathrm{N}$ & 6 & 28.57 \\
\hline 11 & 34.0 & $\mathrm{~N}$ & $\mathrm{~N}$ & $\mathrm{Y}$ & $\mathrm{N}$ & $\mathrm{N}$ & $\mathrm{N}$ & 6 & 28.57 \\
\hline & Yes & 0 & 0 & 9 & 0 & 0 & 1 & & \\
\hline & Weightage & 4 & 2 & 6 & 3 & 1 & 5 & & \\
\hline & SI BM & & & & & & & & 28.57 \\
\hline
\end{tabular}

Table 4

Traffic Volume Data:

\begin{tabular}{|c|c|c|c|}
\hline Year & ADT & Avg PCU/HR & PCU/HR \\
\hline 2010 & 9886 & 4014.60 & 67.00 \\
\hline 2011 & 10341 & 5116.08 & 85.27 \\
\hline 2012 & 10914 & 5319.21 & 88.65 \\
\hline 2013 & 11713 & 5981.97 & 99.70 \\
\hline 2014 & 12473 & 6219.24 & 103.66 \\
\hline 2015 & 13391 & 6918.17 & 115.30 \\
\hline 2016 & 10381 & 5212.57 & 86.87 \\
\hline 2017 & 11798 & 5997.61 & 100.00 \\
\hline 2018 & 12417 & 6113.24 & 101.90 \\
\hline 2019 & 8947 & 3997.57 & 66.63 \\
\hline
\end{tabular}

Table 5

\section{Ranking of Black Spot Locations}

It involves giving suitable weights to different locations. Weights are assigned to different locations on the basis of occurrence of accidents on roads on (0-10) scale.

The factors by which there is increase in occurrence of accidents have lower weights. 
ISSN No:-2456-2165

Each location is assigned total weight and is obtained by adding individual weights and normalizing the value using maximum weight.

\begin{tabular}{|c|c|c|c|}
\hline Code & $\begin{array}{c}\text { Factors affecting occurrence } \\
\text { of accidents }\end{array}$ & $\begin{array}{c}\begin{array}{c}\text { Possible variations in } \\
\text { weights }\end{array} \\
\end{array}$ & Weight assigned \\
\hline $\mathrm{A}$ & Relative severity index & $\begin{array}{c}10-9 \\
9-8 \\
8-7 \\
7-6 \\
6-5 \\
5-4 \\
4-3 \\
3-2 \\
2-1 \\
\end{array}$ & $\begin{array}{c}2 \\
3 \\
4 \\
5 \\
6 \\
7 \\
8 \\
9 \\
10 \\
\end{array}$ \\
\hline $\mathrm{B}$ & $\begin{array}{l}\text { Approximate no. of } \\
\text { vehicles/day }\end{array}$ & $\begin{array}{l}<1200 \\
<2500 \\
<5000 \\
>5000\end{array}$ & $\begin{array}{c}10 \\
7 \\
3 \\
1\end{array}$ \\
\hline $\mathrm{C}$ & Width of road & $\begin{array}{c}\text { Single lane } 3.75 \mathrm{~m} \\
\text { Two lane without raised kerbs } \\
7 \mathrm{~m} \\
\text { Two lane with raised kerbs } \\
7.5 \mathrm{~m}\end{array}$ & $\begin{array}{l}3 \\
2 \\
5\end{array}$ \\
\hline $\mathrm{D}$ & Frequent vehicle type of road & $\begin{array}{c}\text { Carts } \\
\text { Two wheeler } \\
\text { Mixed } \\
\text { Bus/truck }\end{array}$ & $\begin{array}{l}8 \\
5 \\
2 \\
1\end{array}$ \\
\hline $\mathrm{E}$ & Drainage facility provided & $\begin{array}{c}\text { Good } \\
\text { Satisfactory } \\
\text { Poor } \\
\text { No drainage }\end{array}$ & $\begin{array}{l}8 \\
6 \\
4 \\
3\end{array}$ \\
\hline
\end{tabular}

Table 6

Total weight $($ accident prone level $)=\sum($ individual weights $) \times 100 / 110$

\begin{tabular}{|c|c|c|c|c|c|c|}
\hline Place & A & B & $\mathrm{C}$ & $\mathrm{D}$ & $\mathrm{E}$ & APL \\
\hline Shalteng & 3 & 2 & 4 & 6 & 5 & 18.20 \\
\hline Mirgund & 4 & 7 & 6 & 3 & 2 & 20.00 \\
\hline Tappar & 5 & 6 & 2 & 7 & 3 & 20.90 \\
\hline Choora & 5 & 7 & 3 & 4 & 2 & 19.00 \\
\hline Ringi & 7 & 3 & 6 & 4 & 5 & 22.70 \\
\hline Nowgam & 7 & 4 & 2 & 6 & 3 & 20.00 \\
\hline TK College & 2 & 4 & 6 & 5 & 3 & 18.20 \\
\hline
\end{tabular}

Table 7

Thus road link spots with high final weight are less prone to accidents as compared to areas with low final weight. Ranking of sites is done on the basis of their APL values.

- Shalteng

- TK College

- Choora

- Nowgam

- Mirgund

- Pattan

- Tappar
- Hyderpora

- Ringi

\section{RESULTS AND DISCUSSION}

The reading taken on Singhpora pattan to Pantha chowk srinagar highway the then analysed by method of ranking. consistent with importance of the parameter, the foremost important parameter had given minimum rank. the odds after giving rank were calculated and on the idea useful of percentage the accidental black spot was 
identified. The method of ranking is as shown in table 5. It has been concluded that by considering all these parameters by using method of ranking the accidental black spots are often identified. The separate investigation is important to nullify the effect of these parameters so on reduce the severity of accidental black spots.

\section{CONCLUSION}

Since 2004 vehicles have killed $48 \%$ more people including civilians,security forces and militants in J\&k than armed violence according to the Indian home ministry data.NH1A back in 2001 to 2005 was having no revisions and project evaluations. Most probably the government would had not been serious about welfare of people or corruption could have been a reason. J\&K topped the list of high accidental death prone area in a National Crime Records Bureau (NCRB). The menace off stunt biking and speeding bikes on the roads of Kashmir valley is getting grave every passing day and has resulted the death percentage in $\mathrm{J} \& \mathrm{~K}$ in road accidents is $66.5 \%$ against the national percentage of $37.2 \%$. But lately the state government and central government are working to tackle this jeopardizing condition by taking into account road conditions and futuristic approaches. NH1A has been decorated by 2 flyovers from Pantha chowk to Singhpora with 4 traffic light governed intersections, and many policemen all over the critical intersections for safety of road users and to secure law. The efforts of the government now had bear the fruit. And the statistics say it all. It is much secured nowadays from Pantha chowk to Singhpora. But we should improve the chances of accidents to nil.

\section{REFERENCES}

[1]. Dr. L. R. Kadyali, "Principles and practices of Highway Engineering", Khanna

[2]. www.en.wikipedia.org/wiki/Accident

[3]. www.en.wikipedia.org/wiki/Traffic_collision

[4]. www.en.wikipedia.org/wiki/Accident_blackspot

[5]. www.civil.iitb.ac.in/tvm/1111_nptel/582_Accident/pl ain/plain.html

[6]. www.en.wikipedia.org/wiki/National_Highway_1_(In dia)(old_numbering)

[7]. www.timesofindia.indiatimes.com/india/India-losesRs-55k-crore-in-roadaccidents-each-year-says-Unionminister-of-road-transportandhighways/articleshow/45917017.cms

[8]. Police stations (Pattan, Parimpora, Nowgam, Pantha chowk).

[9]. www.jaktrans.nic.in

[10]. www.jktransport.nic.in

[11]. www.dailyexcelsior.com 